\title{
Ethical Aspects of Tissue Engineering: A Review
}

\author{
Rob B.M. de Vries, M.A., M.Sc., ${ }^{1}$ Anke Oerlemans, M.A., M.Sc., ${ }^{1}$ Leen Trommelmans, M.A., M.Sc., ${ }^{2}$ \\ Kris Dierickx, Ph.D., ${ }^{2}$ and Bert Gordijn, Ph.D. ${ }^{1}$
}

Tissue engineering (TE) is a promising new field of medical technology. However, like other new technologies, it is not free of ethical challenges. Identifying these ethical questions at an early stage is not only part of science's responsibility toward society, but also in the interest of the field itself. In this review, we map which ethical issues related to TE have already been documented in the scientific literature. The issues that turn out to dominate the debate are the use of human embryonic stem cells and therapeutic cloning. Nevertheless, a variety of other ethical aspects are mentioned, which relate to different phases in the development of the field. In addition, we discuss a number of ethical issues that have not yet been raised in the literature.

\section{Introduction}

T ISSUE ENGINEERING* (TE) is a promising new field of medical technology. If further developed, it might diminish suffering caused by tissue or organ damage and thereby lead to longer and healthier lives. ${ }^{1}$ However, like other new technologies, TE is not free of ethical challenges. Identifying these ethical questions at an early stage is not only part of science's responsibility toward society, but also in the interest of the field itself: it enables the field to flourish by preventing it from investing time and money in directions that are likely to lack societal support.

Despite high hopes, TE is still in its infancy. There are as yet only a few clinical applications, mainly for skin, cartilage, and bone. ${ }^{2,3}$ However, even though the field is still largely focused on research, it is moving ever more closely to clinical practice. The number of clinical trials is steadily rising. Now, therefore, seems a suitable moment to reflect on the moral implications of this technology: the field has developed far enough to have a sufficiently clear view of the directions in which it is heading and has not yet developed too far, so that there is still opportunity to steer clear of undesirable directions and effects.

TE has not figured prominently in public debates, with the notable exception of research involving the use of human

*We use "tissue engineering" (TE) in the sense of ex vivo TE. An ex vivo tissue-engineering product typically consists of three elements: cells (human, either autologous or allogeneic, or xenogeneic), a supporting structure (e.g., an extracellular matrix or scaffold), and biomolecules (e.g., growth factors). Moreover, these elements are combined in vitro before the construct is implanted in the body. embryonic stem cells (hESCs). In this review, we map which ethical questions related to TE have already been documented in the scientific literature. Further, we discuss which other issues might be raised and which issues require closer attention.

\section{Methods}

To find articles that explicitly pay attention to ethical issues raised by or directly related to $\mathrm{TE}^{\dagger}$ the databases PubMed, EMBASE, and Web of Science were searched using the following combinations of terms: "tissue engineering" \& ethic*, "tissue engineered" \& ethic*, "regenerative medicine" \& ethic ${ }^{*}$, "tissue engineering" \& moral, "tissue engineered" \& moral, and "regenerative medicine" \& moral. The search was limited by date (published before 01-01-2008) and language (English). Papers in which ethic* referred to the product name Ethicon were excluded, as well as papers that contained one of the above-mentioned combinations of search terms, but in which the ethical issues discussed did not pertain to tissue engineering/regenerative medicine. Further, the most important journals in the field of tissue engineering and regenerative medicine-Tissue Engineering, Biomaterials, Journal of Tissue Engineering and Regenerative Medicine, Regenerative Medicine, and the Journal of Regenerative Medicine-were searched using the keywords ethic* and moral. These searches combined yielded 203

\footnotetext{
${ }^{\dagger}$ Authors may have a different or broader conception of TE than we do, but we take their remarks about the ethical aspects of TE into account insofar as they apply to TE in the restricted sense in which we use the term.
}

\footnotetext{
${ }^{1}$ Section Ethics, Philosophy, and History of Medicine, Scientific Institute for Quality of Healthcare, Radboud University Nijmegen Medical Centre, Nijmegen, The Netherlands.

${ }^{2}$ Faculty of Medicine, Centre for Biomedical Ethics and Law, Catholic University of Leuven, Leuven, Belgium.
} 
papers. ${ }^{\star}$ These papers were studied and classified according to the ethical aspects of TE mentioned and to the type of journal in which they appeared.

\section{Results}

\section{Papers classified according to issue}

Table 1 shows the 10 ethical issues ${ }^{\S}$ related to TE that are most frequently mentioned or discussed in the scientific literature. The ethical question that dominates is the use of hESCs. About $70 \%$ of the selected articles refer to the moral problems raised by these cells. These articles range from ethical or ethically oriented papers extensively discussing issues like the moral status of human embryos (e.g., Refs. ${ }^{4-18}$ ) via scientific reviews that describe the moral opposition evoked by hESCs as one of the disadvantages of using these cells (e.g., Refs. ${ }^{19-44}$ ) to research papers that present alternative sources of stem cells-for example, stem cells derived from adult bone marrow, ${ }^{45-49}$ amniotic fluid, ${ }^{50-52}$ placenta, ${ }^{50,53-56}$ or umbilical cord (blood) ${ }^{57-62}$ or acquired through reprogramming of differentiated cells ${ }^{63-66}$ - or ways to acquire hESCs without destroying (viable) embryos. ${ }^{67-72}$

A closely related topic that is also often discussed or mentioned is therapeutic or research cloning. About $20 \%$ of the selected articles refer to the moral problems involved in therapeutic cloning. Some articles merely mention that cloning is considered by many to be morally problematic (e.g., Refs. $8,15,35,37,40,42,63,65,68,69,73-75$ ); other papers elaborate on the ethical objections to this technique. The objections most often discussed are the objection that the creation of a human embryo specifically for research purposes and its subsequent destruction contravene its moral status, $4,6,9,17,20,43,76,77$ the objection that permitting therapeutic cloning will inevitably put us on a slippery slope toward reproductive cloning, 4,9,17,20,29,43,76-78 and ethical questions related to paid egg donation. These latter questions include (1) the risks involved in hyperstimulation of the ovaries and the surgical or transvaginal recovery of oocytes for women who will not directly profit from the donation and (2) the commodification of both oocytes and women. $8,17,20,76,77,79,80$

But the use of hESCs and therapeutic cloning are not the only ethical issues mentioned in the literature. A variety of other questions are discussed, which relate to different phases in the development of the field of TE.

\section{Papers classified according to phase in development}

Classified according to the phase in the development of (the field of) TE to which they seem most relevant, the following ethical issues beyond the use of hESCs and therapeutic cloning are mentioned or discussed.

Fundamental and preclinical research. Four clusters of ethical issues associated with this early phase in the development of

\footnotetext{
the References section does not show all 203 articles. We were particularly interested in ethical aspects of TE beyond the use of embryonic stem cells and therapeutic cloning. Of the papers that address one of these latter two issues only a selection is therefore presented, namely, those papers in which these issues are not only mentioned but also, to some extent, discussed.

SThe objections/arguments described hereafter are not necessarily endorsed by the authors who mention them in their paper.
}

Table 1. Ten Ethical Issues Most Frequently Mentioned

\begin{tabular}{lc}
\hline Ethical issue & $\begin{array}{r}\text { Number } \\
\text { of papers }\end{array}$ \\
\hline Use of hESCs & 140 \\
Therapeutic cloning & 43 \\
Donation: altruism vs. transfer of & 16 \\
$\quad$ property rights & \\
Use of xenogeneic cells/tissue & 14 \\
Informed consent of cell donor & 11 \\
Privacy of cell donor & 9 \\
Contribution of TE to life extension & 9 \\
Ethical aspects of clinical trails & 8 \\
Private banking of umbilical cord blood & 8 \\
Use of fetal cells & 8
\end{tabular}

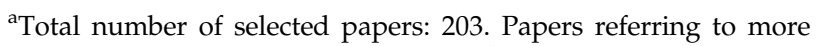
than one issue are grouped under each of these issues.

TE can be distinguished: issues related to (1) the source of cells (to be) used in TE products, (2) the donation of cells, (3) the use of (laboratory) animals, and (4) morally problematic "techniques."

(1) Embryonic stem cells are not the only cells that are considered morally problematic because of their origin. First, several arguments are brought forward against the use of fetal cells, ${ }^{6,17,37,50,73,81-83}$ in particular embryonic germ cells: the primary source of these cells is induced abortion, which is in itself a morally controversial intervention; ${ }^{37,50,73}$ some argue that using fetal tissue from elective abortion is a way of legitimizing abortion and this will encourage institutions to increase the number of abortions; ${ }^{6,73}$ some fear that women might conceive specifically to obtain fetal cells via abortion. ${ }^{6}$

Also controversial is the use of xenogeneic cells or materials for TE purposes. The main arguments mentioned are the risk of introducing pathogenic agents (bacteria, viruses, or other infectious agents) into humans, ${ }^{24,83-94}$ the serious immunological problems xenogeneic cells may cause if they are not genetically altered or physically isolated, $24,83,87,88,91$ and the public acceptability of using animal cells/tissue. ${ }^{87,88,91}$ Some people object to the introduction of animal cells/tissue into the human body as such; others reject the use of material from specific animal species on the basis of religious precepts (e.g., reservations of Muslims and Jews regarding the use of porcine cells/tissue). ${ }^{85}$

Finally, even though the use of allogeneic cells is generally considered to be less problematic than the use of xenogeneic cells, the immunological problems involved in the use of these cells ${ }^{24,90,91,95}$ and the risk of disease transmission ${ }^{24,90,95}$ are sometimes mentioned as reasons against the use of this type of cell.

(2) A second cluster of moral issues pertains to the donation/collection of cells for TE. The requirement of obtaining informed consent is often stressed: donors should be informed as fully as possible about future uses of their tissue/cells, and no tissue/cells may be used without the consent of the donor. ${ }^{4,16,81,96-103}$ Similarly, the importance of protecting the privacy of the donor is pointed out, for example through the anonymization of samples used in scientific research. ${ }^{16,96-98,101-105}$ Further, many au- 
thors indicate that free and unpaid donation is or should be the ideal behind policy/legislation regulating the collection of cells/tissues for research in regenerative medicine. $84,86,90,98,102,103,105,106$

A closely related issue is the question of the ownership of the human body and its parts. ${ }^{13,76,81,95,99-102,104,106}$ This question is sometimes interpreted as a question of who has authority over the use of collected cells/tissue, ${ }^{99,101}$ but more often as a question of whether the human body can be subject to property rights. Acknowledging these rights seems a necessary condition for allowing paid donation and the patenting not only of processes involving human (stem) cells, but also of these cells themselves. ${ }^{13,16,90,102,107-109}$ The reasons most often mentioned against granting property rights are that it would violate human dignity and that it could lead to exploitation of poor people. $13,81,95,106$

Moreover, there is considerable debate about the most desirable mode of banking of umbilical cord blood. ${ }^{54,99,104,110-114}$ Stem cells from this blood might in the future be used for regenerative purposes. Several ethical arguments are advanced for preferring public banks to private, commercial banks that collect cord blood for autologous use. A number of authors stress that at present it is doubtful whether cord blood stem cells will ever be used for autologous transplantation. To claim that cord blood banking is a way to save the key components for future medical treatment of your child is therefore to create false hope. ${ }^{9,104,110-112}$ This is especially problematic because the promotional materials of these commercial banks are targeted at prospective parents at a vulnerable time. ${ }^{104,110-112}$ Moreover, private banks may take cord blood out of circulation that might have been collected by public banks for allogeneic transplantation in unrelated recipients. Donating to private banks therefore conflicts with the principle of solidarity. ${ }^{99,104,112}$

(3) A small number of papers pay attention to the moral justifiability of using animals either as a source of cells or for TE research. ${ }^{88,115,116}$ Laboratory animals are used to study the fundamental processes involved in TE, and they function as models of human disease for testing new products. As several authors ${ }^{115,116}$ stress, these animals can experience substantial discomfort, and experiments should therefore only be performed when no alternatives are available and when the benefit of the experiment outweighs the animals' suffering. On the other hand, several other papers point to the prospects of using human cell cultures and TE products like artificial skin as alternatives for laboratory animals in safety testing or drug discovery. ${ }^{97,117-119}$

(4) Besides objections to therapeutic cloning, moral reservations regarding certain other "techniques" are mentioned, notably regarding the genetic engineering of cells for TE products ${ }^{90,120,121}$ and the mixing of human and animal cells or genetic material (e.g., the use of interspecies nuclear transfer or the engrafting of human ES cells into a mouse blastocyst). ${ }^{74,83,122,123}$

Clinical trials. Although an integral analysis of the ethical aspects of clinical trials with TE products is lacking, a number of issues are discussed. Most important among these are the requirement of informed consent of the participant, ${ }^{16,124,125}$ the importance of and difficulties involved in risk-benefit analysis, ${ }^{16,91,124}$ the need for clear criteria of ef- ficacy and safety, ${ }^{38,86,91,126,127}$ and the desirability of longterm posttrial follow-up including the establishment of a registry. ${ }^{126}$

Clinical practice (short-term). The following issues mentioned in the literature seem to be particularly relevant when TE products are introduced in clinical practice: the informed consent of patients, especially if the product contains xenogeneic material; ${ }^{85,88,93,102}$ in view of public health, the necessity of complying with the regulations of Good Manufacturing \& Laboratory Practice ${ }^{38,86,91,98,105}$ and justice in the distribution of treatments with TE products, both among different groups within Western societies and between these societies and developing countries. ${ }^{84,124,128}$

Advanced clinical application (long-term). Besides the issues previously described, a number of more philosophical questions about TE are raised. The first question can be concisely described by slightly adapting the title of one of the papers about stem cells ${ }^{31}$-TE: immortality or a healthy old age? In other words, should TE only or primarily be used to fight the negative effects of ageing or may it also be deployed in the extension of the human lifespan? ${ }^{15,18,31,90,95,128-132}$ Second, is it morally desirable to use TE to enhance human capabilities? ${ }^{124,128,133}$ And how will TE affect our view of and attitude toward our body? $?^{5,81,90,128,132}$

Distribution among phases. In conclusion, and taking a more quantitative perspective, the preclinical phase is dominant not only in terms of the number of issues associated with it, but also in terms of the number of articles that pay attention to issues most relevant to this phase (Table 2). Even if papers referring to the use of hESCs and therapeutic cloning are not included, more papers pertain to the preclinical phase than to all three later phases combined.

\section{Papers classified according to type of journal}

A large majority of the selected papers are published in scientific/biomedical journals; only a small minority can be found in journals in the domain of (medical) ethics, social science, or the humanities (Table 3). Not all articles in the biomedical journals are purely scientific; some are of a more reflective nature. Nevertheless, by far most authors have a scientific/biomedical affiliation.

\section{Discussion}

Even though the use of hESCs and the closely related topic of therapeutic cloning dominate the scientific literature dealing with the ethical aspects of TE, that does not mean

Table 2. Papers Classified According to Phase in Development TE

\begin{tabular}{lc}
\hline Phase development TE & Number of papers $^{\mathrm{a}}$ \\
\hline Preclinical research & $55^{\mathrm{b}}$ \\
Clinical trials & 8 \\
Clinical practice & 12 \\
Advanced clinical application & 14 \\
\hline
\end{tabular}

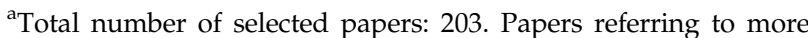
than one issue are grouped under each of these issues.

bPapers referring to hESCs and/or cloning are not included. 
Table 3. Papers Classified According to Type OF JOURNAL

\begin{tabular}{lc}
\hline Type of journal & $\begin{array}{c}\text { Number } \\
\text { of papers }\end{array}$ \\
\hline Biomedical journal & 190 \\
$\begin{array}{l}\text { Other (ethics, social science, } \\
\text { and humanities) }\end{array}$ & 13 \\
\hline
\end{tabular}

that these issues are at present most relevant from an ethical point of view. Current applications of TE are not yet using cells derived from hESCs, and it is unlikely that they will do so in the near future ${ }^{134}$ (although research in this direction is being carried out ${ }^{135-137}$ ). Moreover, even if TE products based on hESCs will be developed, still many TE products will contain other types of (stem) cells. And although there are strong indications that it is in principle possible to acquire human blastocysts through somatic cell nuclear transfer, ${ }^{138}$ it is as yet far from evident that it will be possible to obtain in a safe and efficient way differentiated cells, let alone tissues or organs, derived from hESCs acquired via therapeutic cloning. ${ }^{20,139,140}$ In other words, the strong focus of the debate on the issues of hESCs and therapeutic cloning is not warranted.

Although, apart from hESCs and therapeutic cloning, a large number of ethical issues relevant to the development of TE are already being mentioned in the literature, we believe that there are significant issues that are not yet covered or did not get the attention they deserve (cf. Refs. ${ }^{141-143}$ ). Some of these issues have been discussed in relation to other new medical technologies like cell and gene therapy, but we consider it important that they be explicitly discussed in the context of TE.

First, the need for obtaining informed consent from a cell donor is greatly stressed. However, the problems involved in meeting the ideals of informed consent are hardly discussed: Is it possible to provide all relevant information regarding future uses and tests? If not, will general information suffice?** Will the donor be able to (fully) understand the detailed and scientific information given? If not, what is his/her consent worth? ${ }^{\dagger \dagger}$

Second, although the need for animal models that more closely resemble human diseases is noted, ${ }^{115,123,148-150}$ the significance of this fact for the justifiability of animal experiments is largely ignored. Further, since the TE products that are being developed as alternatives to laboratory animals are not primarily intended to replace experiments for TE research, it is still an open question whether the development of TE will lead to an overall reduction of the number of laboratory animals used.

Third, more attention needs to be paid to the ethical issues involved in clinical trials, ${ }^{*}$ in particular to the significance of the complexity of TE products for dealing with these issues.

**For a similar discussion of the amount of information that is required or desirable for informed consent regarding the collection of tissue samples, see, for example, Refs. ${ }^{144,145}$

${ }^{\dagger}$ For a discussion of similar problems in the context of informed consent for clinical trials, see, for example, Refs. ${ }^{146,147}$

For a general discussion of the ethical issues in clinical trials, see Ref. $^{151}$
TE products are complex in at least the following three respects: (1) TE products show a certain amount of variability because they contain metabolically active cells in the dynamic environment of the extracellular scaffolds; (2) implanting a TE product initiates an ongoing interaction between the product and the recipient's body, which also varies to some extent; (3) implanting a TE product is an irreversible process-once the process of integration and regeneration is initiated, it is impossible to reverse it completely. ${ }^{143}$ This complexity seems to have consequences for the possibility of meeting the requirements of informed consent (cf. consent cell donation), of making an accurate risk-benefit analysis, for the generalizability of the results of trials and for the necessity of a long-term posttrial follow-up. Moreover, since TE is claimed to be part of a new medical paradigm, namely, that of regenerative medicine, it would seem that the goal of a trial testing the efficacy of a TE product should be to demonstrate not only that the treatment is as effective as current treatments, but also that there is in fact regeneration in the body.

Fourth, given that TE products will likely be rather expensive, broad access to these products will be dependent on reimbursement. However, the lack of standards for clinical trials and persisting uncertainty whether treatments with TE products will not only be safe but also more effective than current treatments decrease the likelihood that they will be refunded. But if reimbursement were not provided, application of these products would be the privilege of the happy few, and all the fruits of publicly funded research would be reaped by private hands.

Fifth, two groups of people are likely to benefit especially from TE: young people with congenital diseases, for whom TE might provide a long-term solution superior to any therapy currently available, and the elderly, who suffer more than average from degenerative diseases. In the light of the limited budgets for health care, who should profit most? Apart from the issue of just allocation-which group is most entitled to these treatments?-a number of other considerations seem to be relevant for answering this question. $\$ \S$ Thus, although application for elderly people could significantly increase their quality of life, this application also raises anthropological and socioeconomic questions. Would large-scale application to the problems of the elderly lead to a medicalization of ageing; that is, would ageing increasingly be regarded as a medical problem to be treated rather than as a natural physiological condition? ${ }^{* * *}$ And would application to the elderly aggravate the socioeconomic problems of an ageing society? ${ }^{\dagger \dagger}$ Pediatric applications, on the other hand, raise their own set of problems, for example, regarding the longterm safety and efficacy as well as the validity of the substituted consent given by the parents.

\footnotetext{
${ }^{\$}$ Acknowledging that these considerations are of diverse ethical nature and deserve attention in their own right, we here focus on how they might bear on the question of who should profit most from TE products.

${ }_{* * *}$ The issue of the status of the ageing process has been mainly discussed in the context of research into the extension of the maximum human lifespan, see, for example, Refs. ${ }^{152,153}$

${ }^{\dagger \dagger}$ For a general discussion of the economics and ethics of antiageing interventions, see, for example, Ref. ${ }^{154}$

WFFor a general discussion of the ethical issues in neonatal surgery, see, for example, Ref. ${ }^{155}$
} 
Sixth, even though a few authors ${ }^{128,133}$ mention ethical issues involved in using TE for enhancing the human body, the examples they use (extending the range of our senses or improving cognitive function for healthy individuals through cell-based therapies) are unlikely to be realized in the near future. An application beyond therapy that will probably be available much sooner is the use of TE products for cosmetic purposes (e.g., more natural breast implants; cf. Refs. ${ }^{156,157}$ ). The question of the desirability of such nonmedical applications of TE needs to be addressed. $\$ \S \S$

Although all the above-mentioned issues are relevant for an ethical assessment of TE, they are not equally urgent. We would argue that special attention should presently be devoted to the ethical questions related to clinical trials, because of the stage of development of the field of TE-on the verge from preclinical research to clinical trials-and because of the relatively scarce attention paid to this phase so far. Moreover, the ethical issues involved in the collection of cells (informed consent, privacy/confidentiality, and altruistic vs. paid donation) should remain a focus of reflection, for without an ethically satisfactory regulation of cell donation even preclinical research would/should come to a halt.

The fact that so many papers in scientific/biomedical journals pay attention to potential ethical issues related to TE clearly indicates that tissue engineers already reflect on the ethical aspects of their work. The involvement of professional ethicists, on the other hand, still seems relatively low. We would argue that, to ensure an adequate identification and analysis of the ethical aspects of TE, ethicists should become more engaged in the ethical debate on TE. However, to prevent the ethical reflections from becoming too abstract or irrelevant in the light of scientific developments, close collaboration with scientists in the field of TE is of vital importance. Combining the intellectual capacities of scientists and ethicists should lead to ethical considerations that have both reflective depth and practical relevance.

\section{Acknowledgments}

The research for this contribution was supported by the Dutch Program Tissue Engineering (R.d.V. and B.G.), the EuroSTEC-project, funded by the European Commission, FP6 (A.O.), and the STEPS-project, funded by the European Commission, FP6-500465 (L.T. and K.D.).

\section{References}

1. Langer, R., and Vacanti, J.P. Tissue Engineering. Science 260, 920, 1993.

2. Bock, A.-K., Ibaretta, D., and Rodriguez-Cerezo, E. Human Tissue-Engineered Products. Today's Markets and Future Prospects. JRC-IPTS, 2003.

3. Multi-Agency Tissue Engineering Science (MATES) Interagency Working Group (IWG). Advancing tissue science and engineering: a foundation for the future, p.3, 2007.

4. Cogle, C.R., Guthrie, S.M., Sanders, R.C., Allen, W.L., Scott, E.W., and Petersen, B.E. An overview of stem cell research and regulatory issues. Mayo Clin Proc 78, 993, 2003.

\footnotetext{
$\S \S \S$ For a general discussion of the ethics of cosmetic interventions, see, for example, Refs. ${ }^{158,159}$
}

5. Cooper, M. Regenerative medicine: stem cells and the science of monstrosity. Med Humanit 30, 12, 2004.

6. Daar, A.S., Bhatt, A., Court, E., and Singer, P.A. Stem cell research and transplantation: science leading ethics. Transplant Proc 36, 2504, 2004.

7. Denker, H. Embryonic stem cells: an exciting field for basic research and tissue engineering, but also an ethical dilemma? Cells Tissues Organs 165, 246, 1999.

8. Dickens, B.M., and Cook, R.J. Acquiring human embryos for stem cell research. Int J Gynaecol Obstet 96, 67, 2007.

9. Fischbach, G.D., and Fischbach, R.L. Stem cells: science, policy, and ethics. J Clin Invest 114, 1364, 2004.

10. Henon, P.R. Human embryonic or adult stem cells: an overview on ethics and perspectives for tissue engineering. Adv Exp Med Biol 534, 27, 2003.

11. Holm, S. Are countries that ban human embryonic stem cell research hypocritical? Regen Med 1, 357, 2006.

12. Hug, K. Therapeutic perspectives of human embryonic stem cell research versus the moral status of a human embryo-does one have to be compromised for the other? Medicina (Kaunas) 42, 107, 2006.

13. Resnik, D.B. The commercialization of human stem cells: ethical and policy issues. Health Care Anal 10, 127, 2002.

14. Solbakk, J.H. Stem cell research and the ethics of transparency. Regen Med 1, 831, 2006.

15. Sulmasy, D.P. Promethean medicine: spirituality, stem cells, and cloning. South Med J 99, 1419, 2006.

16. Tsang, L. Legal and ethical status of stem cells as medicinal products. Adv Drug Deliv Rev 57, 1970, 2005.

17. Yoshimura, Y. Bioethical aspects of regenerative and reproductive medicine. Human Cell 19, 83, 2006.

18. Zwanziger, L.L. Biology, ethics, and public policy: deliberations at an unstable intersection. Anat Rec B New Anat 275, 185, 2003.

19. Bongso, A., and Richards, M. History and perspective of stem cell research. Best Pract Res Clin Obstet Gynaecol 18, 827, 2004.

20. Choumerianou, D.M., Dimitriou, H., and Kalmanti, M. Stem cells: promises versus limitations. Tissue Eng Part B Rev 14, 53, 2008.

21. Cortes, J.L., Cobo, F., Barnie, A.H., Catalina, P., Cabrera, C., Nieto, A., Montes, R., and Concha, A. Role of the embryology laboratory in the human embryonic stem cell line derivation process. Cytotechnology 52, 1, 2006.

22. du Toit, D. Stem cell research. SADJ 61, 334, 2006.

23. Findikli, N., Candan, N.Z., and Kahraman, S. Human embryonic stem cell culture: current limitations and novel strategies. Reprod Biomed Online 13, 581, 2006.

24. Garner, J.P. Tissue engineering in surgery. Surgeon 2, 70, 2004.

25. Gudjonsson, T., Thomsen, A.R., Vainio, O., and Ogmundsdottir, H.M. Stem cells. APMIS 113, 725, 2005.

26. Jain, K.K. Stem cell technologies in regenerative medicine. Expert Opin Biol Ther 2, 771, 2002.

27. Jell, G. Stem cells in regenerative medicine. Pharm J 275, 73, 2005.

28. Kansu, E. Current views on stem cell biology and plasticity. Turk J Cancer 33, 69, 2003.

29. Lerou, P.H., and Daley, G.Q. Therapeutic potential of embryonic stem cells. Blood Rev 19, 321, 2005.

30. Lo, K.C., Whirledge, S., and Lamb, D.J. Stem cells: implications for urology. Curr Urol Rep 6, 49, 2005.

31. Mummery, C. Stem cell research: immortality or a healthy old age? Eur J Endocrinol 151 Suppl 3, 7, 2004. 
32. Polak, J.M., and Bishop, A.E. Stem cells and tissue engineering: past, present, and future. Ann NY Acad Sci 1068, 352, 2006

33. Reed, J.A., and Patarca, R. Regenerative dental medicine: stem cells and tissue engineering in dentistry. J Environ Pathol Toxicol Oncol 25, 537, 2006.

34. Reubinoff, B. Current status of human embryonic stem cell research. Reprod Biomed Online 14, 121, 2007.

35. Rippon, H.J., and Bishop, A.E. Embryonic stem cells. Cell Prolif 37, 23, 2004.

36. Rodriguez, C., and Simon, C. Human embryonic stem cell derivation: from the IVF perspective to therapeutic applications. Regen Med 1, 103, 2006.

37. Sadiq, T.S., and Gerber, D.A. Stem cells in modern medicine: reality or myth? J Surg Res 122, 280, 2004.

38. Sievert, K.D., Amend, B., and Stenzl, A. Tissue engineering for the lower urinary tract: a review of a state of the art approach. Eur Urol 52, 1580, 2007.

39. Stoltz, J.F., Bensoussan, D., Decot, V., Ciree, A., Netter, P., and Gillet, P. Cell and tissue engineering and clinical applications: an overview. Biomed Mater Eng 16, S3, 2006.

40. Sylvester, K.G., and Longaker, M.T. Stem cells: review and update. Arch Surg 139, 93, 2004.

41. Turksen, K., and Troy, T.C. Human embryonic stem cells: isolation, maintenance, and differentiation. Methods Mol Biol 331, 1, 2006.

42. Vats, A., Bielby, R.C., Tolley, N.S., Nerem, R., and Polak, J.M. Stem cells. Lancet 366, 592, 2005.

43. Weissman, I. Stem cell research: paths to cancer therapies and regenerative medicine. JAMA 294, 1359, 2005.

44. Wobus, A.M., and Boheler, K.R. Embryonic stem cells: prospects for developmental biology and cell therapy. Physiol Rev 85, 635, 2005.

45. Ballas, C.B., Zielske, S.P., and Gerson, S.L. Adult bone marrow stem cells for cell and gene therapies: implications for greater use. J Cell Biochem Suppl 38, 20, 2002.

46. Körbling, M., Estrov, Z., and Champlin, R. Adult stem cells and tissue repair. Bone Marrow Transplant 32 Suppl 1, S23, 2003.

47. Krampera, M., Pizzolo, G., Aprili, G., and Franchini, M. Mesenchymal stem cells for bone, cartilage, tendon and skeletal muscle repair. Bone 39, 678, 2006.

48. Markowicz, M., Heitland, A., Steffens, G.C.M., Neuss, S., and Pallua, N. Human mesenchymal stem cell implantation and collagen modification as a tool for tissue engineering. Eur J Plast Surg 28, 284, 2005.

49. Tögel, F., and Westenfelder, C. Adult bone marrow-derived stem cells for organ regeneration and repair. Dev Dyn 236, 3321, 2007.

50. Fauza, D. Amniotic fluid and placental stem cells. Best Pract Res Clin Obstet Gynaecol 18, 877, 2004.

51. Perin, L., Giuliani, S., Jin, D., Sedrakyan, S., Carraro, G., Habibian, R., Warburton, D., Atala, A., and de Filippo, R.E. Renal differentiation of amniotic fluid stem cells. Cell Prolif 40, 936, 2007.

52. Prusa, A.R., Marton, E., Rosner, M., Bernaschek, G., and Hengstschlager, M. Oct-4-expressing cells in human amniotic fluid: a new source for stem cell research? Hum Reprod 18, 1489, 2003.

53. Igura, K., Zhang, X., Takahashi, K., Mitsuru, A., Yamaguchi, S., and Takashi, T.A. Isolation and characterization of mesenchymal progenitor cells from chorionic villi of human placenta. Cytotherapy 6, 543, 2004.
54. Katz-Benichou, G. Umbilical cord blood banking: economic and therapeutic challenges. Int J Healthc Technol Manage 8, 464, 2007.

55. Parolini, O., Alviano, F., Bagnara, G.P., Bilic, G., Buhring, H.J., Evangelista, M., Hennerbichler, S., Liu, B., Magatti, M., Mao, N., Miki, T., Marongiu, F., Nakajima, H., Nikaido, T., Portmann-Lanz, C.B., Sankar, V., Soncini, M., Stadler, G., Surbek, D., Takahashi, T.A., Redl, H., Sakuragawa, N., Wolbank, S., Zeisberger, S., Zisch, A., and Strom, S.C. Isolation and characterization of cells from human term placenta: outcome of the first international Workshop on Placenta Derived Stem Cells. Stem Cells 26, 300, 2008.

56. Yen, B.L., Chien, C.C., Chen, Y.C., Chen, J.T., Huang, J.S., Lee, F.K., and Huang, H.I. Placenta-derived multipotent cells differentiate into neuronal and glial cells in vitro. Tissue Eng Part A 14, 9, 2008.

57. Goldberg, J.L., Laughlin, M.J., and Pompili, V.J. Umbilical cord blood stem cells: implications for cardiovascular regenerative medicine. J Mol Cell Cardiol 42, 912, 2007.

58. Harris, D.T., Badowski, M., Ahmad, N., and Gaballa, M.A. The potential of cord blood stem cells for use in regenerative medicine. Expert Opin Biol Ther 7, 1311, 2007.

59. Lee, M.W., Yang, M.S., Park, J.S., Kim, H.C., Kim, Y.J., and Choi, J. Isolation of mesenchymal stem cells from cryopreserved human umbilical cord blood. Int J Hematol 81, 126, 2005.

60. McGuckin, C.P., Forraz, N., Baradez, M.O., Navran, S., Zhao, J., Urban, R., Tilton, R., and Denner, L. Production of stem cells with embryonic characteristics from human umbilical cord blood. Cell Prolif 38, 245, 2005.

61. Wang, H.S., Hung, S.C., Peng, S.T., Huang, C.C., Wei, H.M., Guo, Y.J., Fu, Y.S., Lai, M.C., and Chen, C.C. Mesenchymal stem cells in the Wharton's jelly of the human umbilical cord. Stem Cells 22, 1330, 2004.

62. Weiss, M.L., and Troyer, D.L. Stem cells in the umbilical cord. Stem Cell Rev 2, 155, 2006.

63. Alberio, R., Campbell, K.H., and Johnson, A.D. Reprogramming somatic cells into stem cells. Reproduction 132, 709, 2006.

64. Cai, S., Fu, X.B., and Sheng, Z.Y. Dedifferentiation: a new approach in stem cell research. Bioscience 57, 655, 2007.

65. Collas, P., and Gammelsaeter, R. Novel approaches to epigenetic reprogramming of somatic cells. Cloning Stem Cells 9, 26, 2007.

66. Wernig, M., Meissner, A., Foreman, R., Brambrink, T., Ku, M., Hochedlinger, K., Bernstein, B.E., and Jaenisch, R. In vitro reprogramming of fibroblasts into a pluripotent EScell-like state. Nature 448, 318, 2007.

67. Chung, Y., Klimanskaya, I., Becker, S., Marh, J., Lu, S.-J., Johnson, J., Meisner, L., and Lanza, R. Embryonic and extraembryonic stem cell lines derived from single mouse blastomeres. Nature 439, 216, 2006.

68. Fangerau, H. Can artificial parthenogenesis sidestep ethical pitfalls in human therapeutic cloning? An historical perspective. J Med Ethics 31, 733, 2005.

69. Hipp, J., and Atala, A. Tissue engineering, stem cells, cloning, and parthenogenesis: new paradigms for therapy. J Exp Clin Assist Reprod 1, 3, 2004.

70. Landry, D.W., Zucker, H.A., Sauer, M.V., Reznik, M., and Wiebe, L. Hypocellularity and absence of compaction as criteria for embryonic death. Regen Med 1, 367, 2006. 
71. Weissman, I. Politic stem cells. Nature 439, 145, 2006.

72. Zhang, X., Stojkovic, P., Przyborski, S., Cooke, M., Armstrong, L., Lako, M., and Stojkovic, M. Derivation of human embryonic stem cells from developing and arrested embryos. Stem Cells 24, 2669, 2006.

73. Abouna, G.M. Ethical issues in organ transplantation. Med Princ Pract 12, 54, 2003.

74. Lanza, R.P., Cibelli, J.B., and West, M.D. Prospects for the use of nuclear transfer in human transplantation. Nat Biotechnol 17, 1171, 1999.

75. Romano, G. Perspectives and controversies in the field of stem cell research. Drug News Perspect 19, 433, 2006.

76. Dhai, A., Moodley, J., Quoid-Mason, D.J., and Rodeck, C. Ethical and legal controversies in cloning for biomedical research. A South African perspective. S Afr Med J 94, 906, 2004.

77. Hall, V.J., Stojkovic, P., and Stojkovic, M. Using therapeutic cloning to fight human disease: a conundrum or reality? Stem Cells 24, 1628, 2006.

78. Goldspink, G., MacDermot, K.D., and Novo, F.J. Social and moral implications arising from genetic screening and genetic engineering. Med Princ Pract 7, 150, 1998.

79. Lomax, G.P., Hall, Z.W., and Lo, B. Responsible oversight of human stem cell research: the California Institute for Regenerative Medicine's medical and ethical standards. PLoS Med 4, 803, 2007.

80. Thompson, C. Why we should, in fact, pay for egg donation. Regen Med 2, 203, 2007.

81. Awaya, T. Common ethical issues in regenerative medicine. J Int Bioethique 16, 69, 2005.

82. Fiegel, H.C., Lange, C., Kneser, U., Lambrecht, W., Zander, A.R., Rogiers, X., and Kluth, D. Fetal and adult liver stem cells for liver regeneration and tissue engineering. J Cell Mol Med 10, 577, 2006.

83. Löwenheim, H., Dazert, S., Bucheler, M., and GuntinasLichius, O. Regenerative medicine/cellular engineering for diseases of the head and neck. DNA Cell Biol 22, 547, 2003.

84. Baum, B.J., and Mooney, D.J. The impact of tissue engineering on dentistry. J Am Dent Assoc 131, 309, 2000.

85. Enoch, S., Shaaban, H., and Dunn, K.W. Informed consent should be obtained from patients to use products (skin substitutes) and dressings containing biological material. J Med Ethics 31, 2, 2005.

86. Faulkner, A., Kent, J., Geesink, I., and FitzPatrick, D. Purity and the dangers of regenerative medicine: regulatory innovation of human tissue-engineered technology. Soc Sci Med 63, 2277, 2006.

87. Garner, J.P. Tissue engineering and the trauma surgeon. Trauma 4, 177, 2002.

88. Hammerman, M.R., and Cortesini, R. Organogenesis and tissue engineering. Transpl Immunol 12, 191, 2004.

89. Iijima, K., Igawa, Y., Imamura, T., Moriizumi, T., Nikaido, T., Konishi, I., and Nishizawa, O. Transplantation of preserved human amniotic membrane for bladder augmentation in rats. Tissue Eng 13, 513, 2007.

90. Kent, J., Faulkner, A., Geesink, I., and FitzPatrick, D. Culturing cells, reproducing and regulating the self. Body Society 12, 1, 2006.

91. Longley, D., and Lawford, P. Engineering human tissue and regulation: confronting biology and law to bridge the gaps. Med Law Int 5, 101, 2001.

92. Nieminen, O., and Kurki, P. Risk management for biological products. Int J Pharm Med 18, 149, 2004.
93. Schwab, I.R., Johnson, N.T., and Harkin, D.G. Inherent risks associated with manufacture of bioengineered ocular surface tissue. Arch Ophthalmol 124, 1734, 2006.

94. Tzanakakis, E.S., Hess, D.J., Sielaff, T.D., and Hu, W.S. Extracorporeal tissue engineered liver-assist devices. Annu Rev Biomed Eng 2, 607, 2000.

95. Black, J. Thinking twice about "tissue engineering". IEEE Eng Med Biol Mag 16, 102, 1997.

96. Bredehorn, T., and Rudolph, B. Legal problems in tissue transplantation. Transplant Proc 34, 2345, 2002.

97. Orr, S., Alexandre, E., Clark, B., Combes, R., Fels, L.M., Gray, N., Jönsson-Rylander, A.-C., Helin, H., Koistinen, J., Oinonen, T., Richert, L., Ravid, R., Salonen, J., Teeslau, T., Thasler, W.E., Trafford, J., van der Valk, J., von Versen, R., Weiss, T., Womack, C., and Ylikomi, T. The establishment of a network of European human research tissue banks. Cell Tissue Bank 3, 133, 2002.

98. Pascal, P., Damour, O., Colpart, J.J., and Braye, F. French legal framework relating to human tissues and cells. Med Biol Eng Comput 38, 241, 2000.

99. Salvaterra, E., Lecchi, L., Gobbi, S., and Rebulla, P. The ethics of cord blood banking in light of ownership, informed consent, and solidarity. Cell Preserv Technol 4, 91, 2006.

100. Samanta, A., Samanta, J., and Price, D. Who owns my body - thee or me? The human tissue story continues. Clin Med 4, 327, 2004.

101. Thasler, W.E., Weiss, T.S., Schillhorn, K., Stoll, P.T., Irrgang, B., and Jauch, K.W. Charitable State-Controlled Foundation Human Tissue and Cell Research: Ethic and Legal Aspects in the Supply of Surgically Removed Human Tissue For Research in the Academic and Commercial Sector in Germany. Cell Tissue Bank 4, 49, 2003.

102. Trommelmans, L., Selling, J., and Dierickx, K. A critical assessment of the directive on tissue engineering of the European union. Tissue Eng 13, 667, 2007.

103. Trouet, C. New European guidelines for the use of stored human biological materials in biomedical research. J Med Ethics 30, 99, 2004.

104. Gunning, J. Umbilical cord cell banking-implications for the future. Toxicol Appl Pharmacol 207, 538, 2005.

105. Sanzenbacher, R., Dwenger, A., Schuessler-Lenz, M., Cichutek, K., and Flory, E. European regulation tackles tissue engineering. Nat Biotechnol 25, 1089, 2007.

106. Smith, D.S. The government's role in advancing regenerative medicine and tissue engineering-science, safety, and ethics. Periodontol 2000 41, 16, 2006.

107. Heinonen, M., Oila, O., and Nordstrom, K. Current issues in the regulation of human tissue-engineering products in the European Union. Tissue Eng 11, 1905, 2005.

108. Salter, B. Patenting, morality and human embryonic stem cell science: bioethics and cultural politics in Europe. Regen Med 2, 301, 2007.

109. Williams, G. Patenting of stem cells. Regen Med 1, 697, 2006.

110. Fisk, N.M., Roberts, I.A.G., Markwald, R., and Mironov, V. Can routine commercial cord blood banking be scientifically and ethically justified? PLoS Med 2, 87, 2005.

111. Kurtzberg, J., Lyerly, A.D., and Sugarman, J. Untying the Gordian knot: policies, practices, and ethical issues related to banking of umbilical cord blood. J Clin Invest 115, 2592, 2005.

112. Moise, K.J., Jr. Umbilical cord stem cells. Obstet Gynecol 106, 1393, 2005. 
113. Rebulla, P. Biobanking in the year 2007. Transfus Med Hemother 34, 286, 2007.

114. Thiel, G.T. 40 projects in stem cell research, tissue engineering, tolerance induction and more (NRP46 "Implants and Transplants" 1999-2006). Swiss Med Wkly 137 Suppl 155, 3S, 2007.

115. Madeddu, P., Emanueli, C., Spillmann, F., Meloni, M., Bouby, N., Richer, C., Alhenc-Gelas, F., Van Weel, V., Eefting, D., Quax, P.H., Hu, Y., Xu, Q., Hemdahl, A.L., van Golde, J., Huijberts, M., de Lussaret, Q., Struijker Baudier, H., Couffinhal, T., Duplaa, C., Chimenti, S., Staszewsky, L., Latini, R., Baumans, V., and Levy, B.I. Murine models of myocardial and limb ischemia: diagnostic end-points and relevance to clinical problems. Vascul Pharmacol 45, 281, 2006.

116. Nordgren, A. Moral imagination in tissue engineering research on animal models. Biomaterials 25, 1723, 2004.

117. de Brugerolle, A. SkinEthic Laboratories, a company devoted to develop and produce in vitro alternative methods to animal use. ALTEX 24, 167, 2007.

118. Sartipy, P., Björquist, P., Strehl, R., and Hyllner, J. The application of human embryonic stem cell technologies to drug discovery. Drug Discov Today 12, 688, 2007.

119. Sladowski, D., Combes, R., van der Valk, J., Nawrot, I., and Gut, G. ESTIV questionnaire on the acquisition and use of primary human cells and tissue in toxicology. Toxicol In Vitro 19, 1009, 2005.

120. Heng, B.C., Hong, Y.H., and Cao, T. Modulating gene expression in stem cells without recombinant DNA and permanent genetic modification. Cell Tissue Res 321, $147,2005$.

121. Kang, K.A. Tissue engineering as a subdivision of bioprocess engineering: reparative tissue engineering as a subspecialty of tissue engineering. Ann NY Acad Sci 961, 216, 2002.

122. Minger, S. Interspecies SCNT-derived human embryos: a new way forward for regenerative medicine. Regen Med 2, 103, 2007.

123. Steindler, D.A. Stem cells, regenerative medicine, and animal models of disease. ILAR J 48, 323, 2007.

124. Ebbesen, M., and Jensen, T.G. Nanomedicine: techniques, potentials, and ethical implications. J Biomed Biotechnol 2006, 1, 2006.

125. Mazhari, R., and Hare, J.M. Advances in cell-based therapy for structural heart disease. Prog Cardiovasc Dis 49, 387, 2007.

126. Williams, D. A registry for tissue engineering clinical trials. Med Device Technol 17, 8, 2006.

127. Yoo, M.Y. Government regulations on cellular therapy and proposed approach related with these products by KFDA. Yonsei Med J 45 Suppl, 5, 2004.

128. Satava, R.M. Biomedical, ethical, and moral issues being forced by advanced medical technologies. Proc Am Philos Soc 147, 246, 2003.

129. de Grey, A. Strategies for engineered negligible senescence-why genuine control of aging may be foreseeable: preface. Ann NY Acad Sci 1019, xv, 2004.

130. Mauron, A. The choosy reaper. EMBO Rep 6, 67, 2005.

131. Stock, G. From regenerative medicine to human design: what are we really afraid of? DNA Cell Biol 22, 679, 2003.

132. Thacker, E. Bio-X: removing bodily contingency in regenerative medicine. J Med Humanit 23, 239, 2002.

133. Chan, S., and Harris, J. Cognitive regeneration or enhancement: the ethical issues. Regen Med 1, 361, 2006.
134. Metallo, C.M., Azarin, S.M., Lin, J., de Pablo, J.J., and Palecek, S.P. Engineering tissue from human embryonic stem cells. J Cell Mol Med 12, 709, 2008.

135. Inanç, B., Elçin, A.E., Unsal, E., Balos, K., Parlar, A., and Elçin, Y.M. Differentiation of human embryonic stem cells on periodontal ligament fibroblasts in vitro. Artif Organs 32, 100, 2008

136. Jukes, J.M., Moroni, L., van Blitterswijk, C.A., and de Boer, J. Critical steps toward a tissue-engineered cartilage implant using embryonic stem cells. Tissue Eng Part A 14, 135, 2008.

137. Tremoleda, J.L., Forsyth, N.R., Khan, N.S., Wojtacha, D., Christodoulou, I., Tye, B.J., Racey, S.N., Collishaw, S., Sottile, V., Thomson, A.J., Simpson, A.H., Noble, B.S., and McWhir, J. Bone tissue formation from human embryonic stem cells in vivo. Cloning Stem Cells 10, 119, 2008.

138. French, A.J., Adams, C.A., Anderson, L.S., Kitchen, J.R., Hughes, M.R., and Wood, S.W. Development of human cloned blastocysts following somatic cell nuclear transfer (SCNT) with adult fibroblasts. Stem Cells 26, 485, 2008.

139. Atala, A. Engineering tissues, organs and cells. J Tissue Eng Regen Med 1, 83, 2007.

140. Vajta, G. Somatic cell nuclear transfer in its first and second decades: successes, setbacks, paradoxes and perspectives. Reprod Biomed Online 15, 582, 2007.

141. Gordijn, B. 2006. Medical Utopias. Ethical Reflections about Emerging Medical Technologies. Leuven: Peeters, 2006.

142. Horstman, K. From laboratory to practice: learning about normative issues. In: Doorn, M., ed. Converging Technologies. The Hague: STT, 2005, pp. 134-155.

143. Trommelmans, L., Selling, J., and Dierickx, K. Ethical Issues in Tissue Engineering. Leuven: European Ethical-Legal Papers No. 7, 2007.

144. Bauer, K., Taub, S., and Parsi, K. Ethical issues in tissue banking for research: a brief review of existing organizational policies. Theor Med Bioeth 25, 113, 2004.

145. Nilstun, T., and Hermeren, G. Human tissue samples and ethics: attitudes of the general public in Sweden to biobank research. Med Health Care Philos 9, 81, 2006.

146. Wendler, D. Can we ensure that all research subjects give valid consent? Arch Intern Med 164, 2201, 2004

147. Jefford, M., and Moore, R. Improvement of informed consent and the quality of consent documents. Lancet Oncol 9, 485, 2008.

148. Hunziker, E.B. Tissue engineering of bone and cartilage. From the preclinical model to the patient. Novartis Found Symp 249, 70, 2003.

149. Rashid, S.T., Salacinski, H.J., Hamilton, G., and Seifalian, A.M. The use of animal models in developing the discipline of cardiovascular tissue engineering: a review. Biomaterials 25, 1627, 2004.

150. Wakeman, D.R., Crain, A.M., and Snyder, E.Y. Large animal models are critical for rationally advancing regenerative therapies. Regen Med 1, 405, 2006.

151. Emanuel, E., Wendler, D., and Grady, Ch. What makes clinical research ethical? JAMA 283, 2701, 2000.

152. Partridge, B., and Hall, W. The search for Methuselah: should we endeavour to increase the maximum human lifespan? EMBO Rep 8, 888, 2007.

153. Stock, G., Callahan, D., and de Grey, A. (mod.). Debate: the ethics of life extension. Rejuvenation Res 10, 407, 2007.

154. McConnel, Ch., and Turner, L. Medicine, ageing and human longevity: the economics and ethics of anti-ageing interventions. EMBO Rep 6, S59, 2005. 
155. Caniano, D. Ethical issues in the management of neonatal surgical anomalies. Semin Perinatol 28, 240, 2004.

156. Patrick, Ch. Breast tissue engineering. Annu Rev Biomed Eng 6, 109, 2004.

157. Moseley, T., Zhu, M., and Hedrick, M. Adipose-derived stem and progenitor cells as fillers in plastic and reconstructive surgery. Plast Reconstr Surg 118, S121, 2006.

158. Miller, F., Brody, H., and Chung, K. Cosmetic surgery and the internal morality of medicine. Camb Q Healthc Ethics 9, $353,2000$.

159. Little, M. Cosmetic surgery, suspect norms, and the ethics of complicity. In: Parens, E., ed. Enhancing Human Traits. Washington, DC: Georgetown University Press, pp. 162-176, 2000.
Address reprint requests to: Rob B.M. de Vries, M.A., M.Sc.

Section Ethics, Philosophy, and History of Medicine Scientific Institute for Quality of Healthcare Radboud University Nijmegen Medical Centre

PO Box 9101 6500 HB Nijmegen The Netherlands

E-mail: R.deVries@iq.umcn.nl Received: April 3, 2008 Accepted: July 23, 2008 
